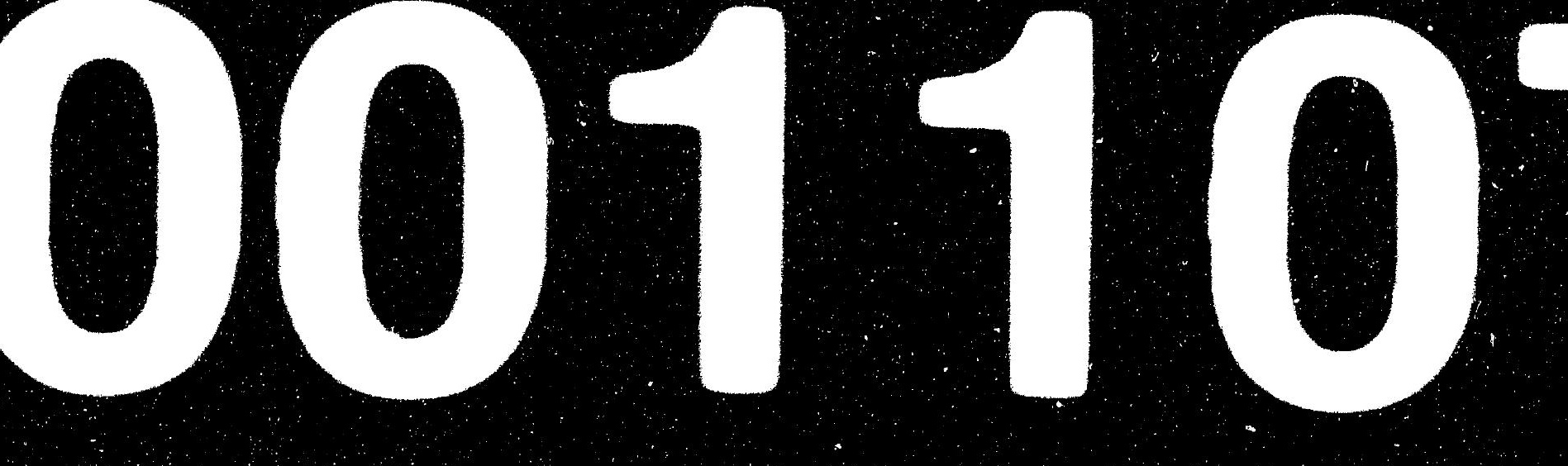

(1)

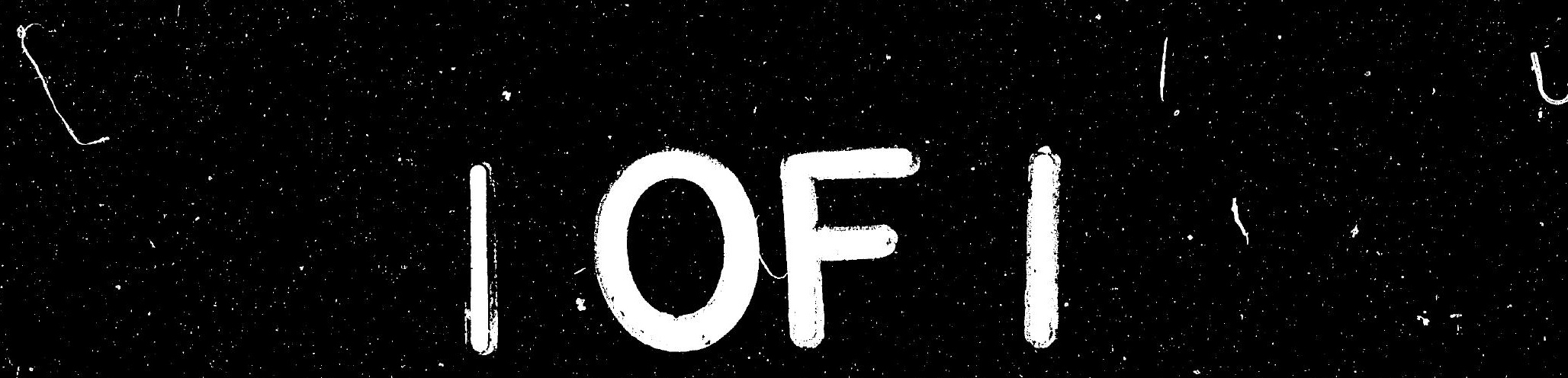

$1=$

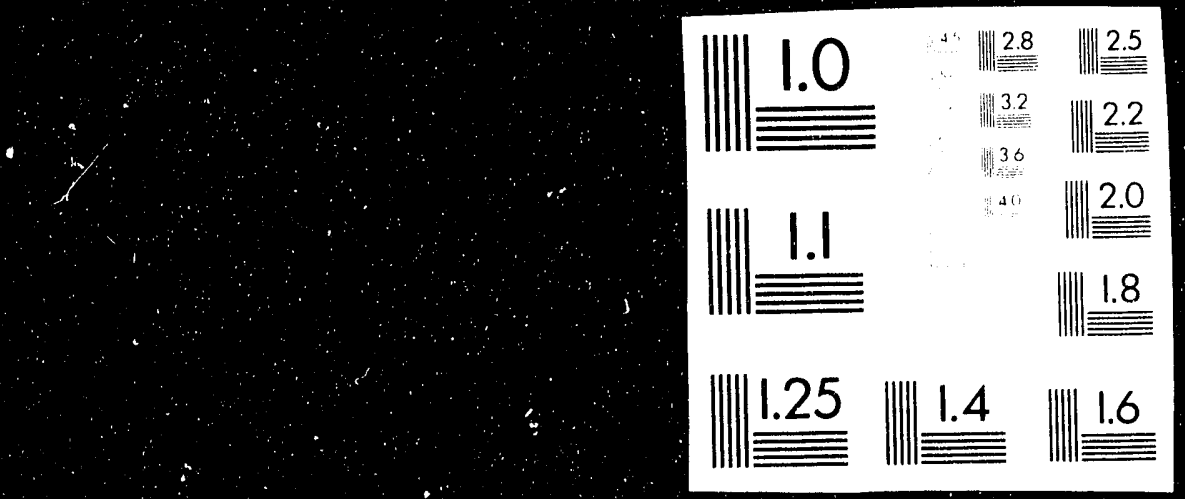

\begin{tabular}{|c|c|}
\hline|||||| .0 & 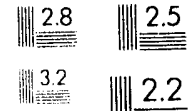 \\
\hline & 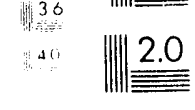 \\
\hline & |||||||1.8 \\
\hline & \\
\hline
\end{tabular}

i. - - 


\title{
A Preliminary Investigation of Acid-Catalyzed Polymerization Reactions of Shale Oil Distillates
}

\author{
Topical Report
}

\author{
D.A. Netzel
}

\author{
DISCLAIMER
}

April 1991

\begin{abstract}
This report was prepared as an account of work sponsored by an agency of the United States This report was prepared as an account of work sponsored by an agency thereof, nor any of their employees, makes any warranty, express or implied, or assumes any legal liability or responsiemployees, makes any warranty, express or implied, or ass information, apparatus, product, or bility for the accuracy, completeness, or usefulness of any information, apparatus, product, or process disclosed, or represents that its use would not infringe privately owned rights. Reference herein to any specific commercial product, process, or service by trade name, trademark, manufacturer, or otherwise does not nucessarily constitute or imply its endorsement, The views mendation, or favoring by the United States Gov.rnment or any agency thereof. The views and opinions of authors expressed herein do not

United States Government or any agency thereof.
\end{abstract}

Work Performed Under Cooperative Agreement No.: DE-FC21-86MC11076

For

U.S. Department of Energy

Office of Fossil Energy

Morgantown Energy Technology Center

Morgantown, West Virginia

By

Western Research Institute

Laramie, Wyoming

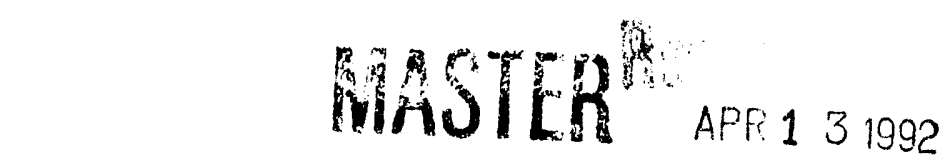




\section{DISCLAIMER}

This report was prepared as an account of work sponsored by an agency of the United States Government. Neither the United States Government nor any agency thereof, nor any of their employees makes any warranty, express or implied, or assumes any legal liability or responsibility for the accuracy, completeness or usefulness of any information, apparatus, product, or process disclosed, or represents that its use would not infringe privately owned rights. Reference herein to any specific commercial product, process, or service by trade name, trademark, manufacturer, or otherwise, does not necessarily constitute or imply its endorsement, recommendation, or favoring by the United States Government or any agency thereof. The views and opinions of authors expressed herein do not necessarily state or reflect those of the United States Government or any agency thereof.

I nis report has been reproduced directly from the best available copy.

Available to DOE and DOE contractors from the Office of Scientific and Technical Information, P.O. Box 62, Oak Ridge, TN 37831; prices available from (615)576-8401, FTS 626-8401.

Available to the public from the National Technical Information Service, U.S. Department of Commerce, 5285 Port Royal Rd., Springfield, VA 22161. 


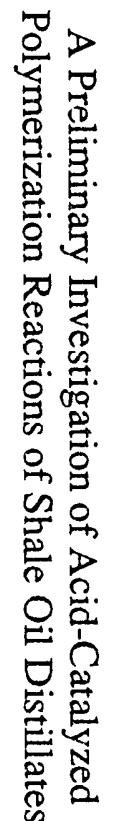




\title{
A Preliminary Investigation of Acid-Catalyzed Polymerization Reactions of Shale Oil Distillates
}

\author{
Topical Report
}

D.A. Netzel

Work Performed Under Cooperative Agreement No.: DE-FC21-86MC11076

For

U.S. Department of Energy Office of Fossil Energy

Morgantown Energy Technology Center

P.O. Box 880

Morgantown, West Virginia 26507-0880

By

Western Research Institute

P.O. Box 3395

University Station

Laramie, Wyoming 82071-3395 
LIST OF TABLES $\ldots \ldots \ldots \ldots \ldots \ldots \ldots \ldots \ldots \ldots \ldots \ldots \ldots \ldots \ldots \ldots \ldots$

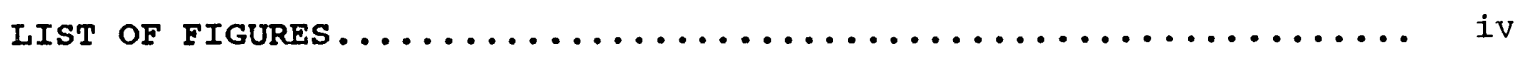

SUMMARY $\ldots \ldots \ldots \ldots \ldots \ldots \ldots \ldots \ldots \ldots \ldots \ldots \ldots \ldots \ldots \ldots \ldots \ldots \ldots \ldots \ldots \ldots \ldots$

INTRODUCTION ...................................

EXPERIMENTAL $\ldots \ldots \ldots \ldots \ldots \ldots \ldots \ldots \ldots \ldots \ldots \ldots \ldots \ldots \ldots \ldots \ldots \ldots \ldots \ldots$

sample preparation............................... 1

Chemical Treatment of the Western Shale oil Distillates...... 2

Nuclear Magnetic Resonance (NMR) ...................... 2

RESULTS AND DISCUSSION............................ 3

Reactions of Shale oil Distillates with Anhydrous $\mathrm{AlCl}_{3} \ldots \ldots . . .4$

Reactions of Shale oil Distillates with $858 \mathrm{H}_{2} \mathrm{SO}_{4} \ldots \ldots \ldots \ldots \ldots$

ConcLustons ..................................... 12

ACKNOWLEDGEMENT .................................. 13

DISCLAIMER $\ldots \ldots \ldots \ldots \ldots \ldots \ldots \ldots \ldots \ldots \ldots \ldots \ldots \ldots \ldots \ldots \ldots \ldots \ldots \ldots$

REFERENCES................................... 14 
1. Results of Chromatographic separation of the Distillates from Western shale oil, wt 8

2. NMR Hydrogen and Carbon contents for Three Western Shale oil Distillates Treated with Anhydrous $\mathrm{AlCl}_{3}$ and $858 \mathrm{H}_{2} \mathrm{SO}_{4}$, atom $8 \ldots \ldots \ldots \ldots \ldots \ldots \ldots$

3. ${ }^{1} \mathrm{H}$ and ${ }^{13_{C}}$ NMR Chemical shift Ranges ................ 10

\section{LIST OF FIGURES}

\section{Figure}

Page

1. $1_{H}$ NMR Spectrum of Western Shale oil Naphtha Distillate.... 6

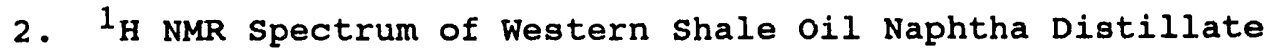
After $\mathrm{H}_{2} \mathrm{SO}_{4}$ Treatment.......................... 7

3. ${ }^{13} \mathrm{C}$ NMR Spectrum of Western Shale oil Naphtha Distillate.... 8

4. ${ }^{13} \mathrm{C}$ NMR Spectrum of Western Shale Oil Naphtha Distillate

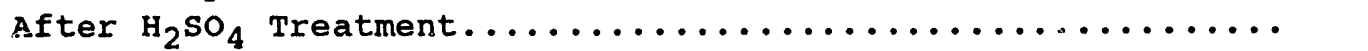


Sinor (1989) reported that a major specialty market may exist for shale oil as an asphalt blending material. Shale oil can be converted to an asphalt blending material by acid catalyzed condensation and polymerization reactions of the many molecular species comprising the composition of shale oil. To simplify the investigation, crude shale oil was separated by distiliation into three distillates of different hydrocarbon and heteroaromatic compositions. These distillates were then treated with two different types of acids to determine the effect of acid type on the end products. Three western shale oil distillates, a naphtha, a middle distillate, and an atmospheric gas oil, were reacted with anhydrous $\mathrm{AlCl}_{3}$ and $858 \mathrm{H}_{2} \mathrm{SO}_{4}$ under low-severity conditions. At relatively low temperatures, little change in the hydrocarbon composition was noted for the Alcl 3 reactions. AlCl $3_{3} \cdot s$ ludge (a polymerized product and/or complex) was formed. However, it is assumed that the sludge was mainly the result of heteroaromatic- $\mathrm{AlCl}_{3}$ reactions.

The reaction of $858 \mathrm{H}_{2} \mathrm{SO}_{4}$ at room temperature with the three distillates produced oils with higher saturate hydrogen contents and no olefins. The increase in saturate hydrogen content is the result of polymerization of the olefinic molecules. A decrease in aromatic carbon content was observed for the reaction of the distillates with $\mathrm{H}_{2} \mathrm{SO}_{4}$. This is the result of the formation of alkylbenzene sulfonates, which were removed from the oils during the aqueous-phase separation procedure. The formation of a highly viscous, tar-like residue was observed after one month for all three treated distillates.

The reactions of the distillates with anhydrous $\mathrm{AlCl}_{3}$ and $\mathrm{H}_{2} \mathrm{SO}_{4}$ at higher temperatures can produce more readily polymerized oils that may be useful as a specialty product for asphalt modification. 


\section{INTRODUCTION}

For shale oil to compete with petroleum in its many uses, extreme upgrading of the shale oil is necessary. However, large-scale mining and upgrading facilities do not appear to be a viable economical option at this time. It may be feasible instead to produce shale oil on a smaller scale than envisioned in the past and to derive products from shale oil that are unique and not competitive with petroleum. Nearterm development of oil shale may depend upon finding a specialty or niche market for shale oil products based on their differences in chemical and physical properties from that of petroleum.

A study was conducted to assess the niche market for a small-scale western oil shale project (sinor 1989). It was reported that the economic feasibility of a small-scale oil shale project can be greatly enhanced by focusing on nonfuel products and that from a technical standpoint, the variety of products that can be made from shale oil is almost unlimited.

Shale oil is an extremely complex material consisting of 1000 to 3000 identifiable compounds. However, according to sinor (1989), no more than 5 to 10 percent of a barrel of raw shale oil can be separated and sold as individual chemicals. sinor further reports that a major market may exist for shale oil as an asphalt blending material. Iittle information has been reported in the literature on upgrading shale oil by direct chemical means exclusive of catalytic refinery processes. Undoubtedly, much chemistry is known about shale oil reactions, but the information is not published.

Two basic chemical reactions that can be used to alter the chemical composition of shale oil distillates are oxidation and polymerization. These processes can be used to economically enhance the end-product use of a shale oil crude as an asphalt or asphalt blending material.

The objective of this investigation was to conduct preliminary acid-catalyzed polymerization experiments on three shale oil distillates in an effort to increase the molecular weight and, thus, the viscosity of the distillates. Acid catalyzed polymerization experiments were carried out using a Lewis acid $\left(\mathrm{AlCl}_{3}\right)$ and a Brönsted acid $\left(858 \mathrm{H}_{2} \mathrm{SO}_{4}\right)$. The extent of chemical changes in the shale oil distillates upon acid treatment was monitored by changes in the ${ }^{1} \mathrm{H}$ and ${ }^{13} \mathrm{C}$ NMR spectra. The extent of physical changes such as an increase in molecular weight and, therefore, viscosity due to condensation and polymerization was determined by visual observation of the samples before and after acid treatment of the distillates.

\section{EXPERIMENTAL}

\section{Sample Preparation}

A complete description of the method of production and the chemical and physical properties of the western shale oil distillates used in this investigation is given by Thomas and Hunter (1989). However, for completeness of this report, a brief description of the preparation of the distillates is given. 
The whole shale oil sample (55 gallons) obtained from the Unocal shale oil production facilities located at Parachute, colorado, was distilled to produce the following distillates and residue: IBP $-350^{\circ} \mathrm{F}$

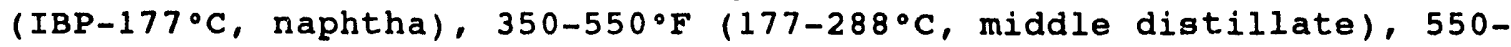
$800^{\circ} \mathrm{F}\left(288-427^{\circ} \mathrm{C}\right.$, atmospheric gas oil), $800-1000^{\circ} \mathrm{F}\left(427-538^{\circ} \mathrm{C}\right.$, vacuum gas oil), and $1000^{\circ} \mathrm{F}\left(538^{\circ} \mathrm{C}+\right.$ residue). An atmospheric distillation using a packed column was conducted to $670^{\circ} \mathrm{F}\left(354^{\circ} \mathrm{C}\right)$. Above this temperature, a continuous vacuum still was used until a final distillate temperature of $1000^{\circ} \mathrm{F}\left(538^{\circ} \mathrm{C}\right)$ was reached. The maximum pot temperature for the atmospheric distillation was $600^{\circ} \mathrm{F}\left(316^{\circ} \mathrm{C}\right)$, and the continuous vacuum distillation temperature was $658^{\circ} \mathrm{F}\left(348^{\circ} \mathrm{C}\right)$. This latter temperature was required to make the $1000^{\circ} \mathrm{F}\left(538^{\circ} \mathrm{C}\right)$ cut at $1 \mathrm{~mm}$ of mercury vacuum. No evidence of thermal cracking was observed during either of the distillations. The atmospheric gas oil distillate was the combination of the atmospheric distillate fraction from $550-600^{\circ} \mathrm{F}$ $\left(288-316^{\circ} \mathrm{C}\right)$ and the vacuum distillate fraction from 600-800\% $(316-$ $427^{\circ} \mathrm{C}$ ). Chemical treatment of the shale oil was performed on only the naphtha, middle distillate, and atmospheric gas oil distillates.

\section{Chemical Treatment of the Western Shale Oil Distillates}

The three distillates were reacted separately with a Lewis acid $\left(\mathrm{AlCl}_{3}\right)$ and a Brönsted acid $\left(\mathrm{H}_{2} \mathrm{SO}_{4}\right)$. The resulting oil products were characterized by ${ }^{1} \mathrm{H}$ and ${ }^{13_{C}}$ NMR spectroscooic techniques.

A 30-mL sample of each the three western shale oil distillates was treated slowly and directly with $1 \mathrm{~g}$ of anhydrous $\mathrm{AlCl}_{3}$. The $\mathrm{AlCl}_{3}$ reactions were carried out at $149^{\circ} \mathrm{F}\left(65^{\circ} \mathrm{C}\right)$ for several hours. Upon completion of the reaction, the mixtures were cooled using an ice bath to $68^{\circ} \mathrm{F}\left(20^{\circ} \mathrm{C}\right)$, and diethyl ether was added. Distilled water was added and the oil-ether and water phases were separated. The oil-ether phase for each distillate product oil was dried with $20 \mathrm{~g}$ of anhydrous $\mathrm{MgSO}_{4}$, and the ether was removed by roto-vap distillation. The resulting product oil for each shale oil distillate was analyzed by NMR.

Each shale oil distillate (11 mL each) was reacted with $25 \mathrm{~mL}$ of an 858 solution of $\mathrm{H}_{2} \mathrm{SO}_{4}$. The acid was added slowly to the distillates. The temperature was maintained at $50^{\circ} \mathrm{F}\left(10^{\circ} \mathrm{C}\right)$ over one-half hour. Upon completion of the reaction, the mixtures were diluted with $-500 \mathrm{~mL}$ of water. To each mixture was added $250 \mathrm{~mL}$ of chloroform, and the resulting phases were separated. To the oil-chloroform phase, $20 \mathrm{~g}$ of anhydrous $\mathrm{MgSO}_{4}$ was added. After the oil-chloroform phase had dried for 24 hours, the chloroform was removed by roto-vap distillation. The product oil from the reaction of $858 \mathrm{H}_{2} \mathrm{SO}_{4}$ with each of the three distillates was analyzed by NMR.

\section{Nuclear Magnetic Resonance (NMR) Analysis}

A JEOL GSX-270 NMR spectrometer was used to obtain both the ${ }^{1} \mathrm{H}$ and ${ }^{13} \mathrm{C}$ liquid-state NMR spectra. The experimental conditions to obtain a ${ }^{1} \mathrm{H}$ spectrum were 8 scans, pulse width of $5.4 \mu \mathrm{s}\left(-45^{\circ}\right)$, acquisition time of $1.5 \mathrm{~s}$, pulse delay of $20 \mathrm{~s}$, and $16 \mathrm{~K}$ time domain data points. The conditions for obtaining a ${ }^{13} \mathrm{C}$ spectrum were 320 scans, pulse width of $9.3 \mu \mathrm{s}\left(90^{\circ}\right)$, acquisition time of $0.8 \mathrm{~s}$, pulse delay of $20 \mathrm{~s}, 32 \mathrm{~K}$ time domain data points, and gated decoupling with the decoupler on during data acquisition. 
The original distillates and the acid-treated distillates were dissolved ( $1: 1$ by volume) in $\mathrm{CDCl}_{3}$ containing 0.48 tetramethylsilane (TMS). These solutions were used to obtain the ${ }^{1} \mathrm{H}$ NMR spectra. For ${ }^{3} \mathrm{C}$ NMR spectra, a second set of solutions of the distillate and $\mathrm{CDCl}_{3}$ were prepared. These solutions contained -0.48 TMS, as the internal chemical-shift reference, and were -0.05 M in chromium(III) acetylacetonate $\left[\mathrm{Cr}(\mathrm{ACAC})_{3}\right]$, as a relaxation reagent. All solutions for ${ }^{H}$ and ${ }^{13} \mathrm{C}$ spectral analyses were transferred to 5 -mm NMR tubes.

\section{RESULTS AND DISCUSSION}

Because western shale oil crude contains a large number of saturate, olefinic, aromatic, and polar-aromatic molecules with a wide range of molecular weights, the crude was fractionated into three distillates: (1) naphtha, (2) middle distillate, and (3) atmospheric gas oil to simplify the experimental investigation. The weight percents of the class composition of the three distillates are listed in Table 1 from Thomas and Hunter (1989). These data show a significant decrease in aromatic hydrocarbon content with a corresponding increase in polar aromatics as the distillate temperature range increases. The middle distillate contains the lowest percentage of saturates and the highest percentage of olefins.

It is expected that the reactions of the Lewis acid, $\mathrm{AlCl}_{3}$, and the Brönsted acid, $\mathrm{H}_{2} \mathrm{SO}_{4}$, with each distillate will significantly alter the chemical composition because both acid types promote isomerization, condensation, and polymerization reactions among the various molecular types present.

The ${ }^{1}$ H NMR data were interpreted as atom percent of aromatic, olefinic, and saturate hydrogens in the original and acid-treated distillates. The ${ }^{13} \mathrm{C}$ NMR data were evaluated as atom percent of aromatic and saturate carbons in the distillates. Duplicate $1_{H}$ NMR analyses of the three distillates show that the maximum absolute error for the atom percent of hydrogen types in the distillates is \pm 2.58 . Table 2 lists the atom percent of hydrogen and carbon types for the three original distillates and the acid treated distillates.

Changes in the composition of the original naphtha distillate upon treatment with $858 \mathrm{H}_{2} \mathrm{SO}_{4}$ are readily apparent. This is shown by the hydrogen-1 spectra in Figures 1 and 2 and the carbon-13 spectra in Figures 3 and 4 . This set of spectra is typical of the changes observed for the other distillates. Table 3 lists the chemical shift range for the hydrogen and carbon types shown in Figures 1-4. 
Table 1. Results of Chromatographic separation of the Distillates from Western shale Oil, wt o

\begin{tabular}{cccc}
\hline & & \\
Chromatographic & Naphtha & Middle & Atmospheric \\
Fraction & & Distillate & Gas Oil \\
& $($ IBP-350 $\mathrm{F})$ & $\left(350-550^{\circ} \mathrm{F}\right)$ & $\left(550-800^{\circ} \mathrm{F}\right)$
\end{tabular}

$\begin{array}{lccc}\text { Saturates (alkanes) } & 41.3 & 31.3 & 34.8 \\ \text { Olefing (alkenes) } & 20.8 & 27.3 & 19.6 \\ \text { Aromatics } & 37.9 & 28.5 & 19.0 \\ \text { Polar Aromatics } & 0 & 12.9 & 26.6 \\ \text { Asphaltenes } & 0 & 0 & 0\end{array}$

a chromatographic data corrected using mass spectral results.

b From mass spectral data

Reactions of Shale Oil Distillates with Anhydrous AlCl 3

\section{Saturate Hydrocarbons}

Aluminum chloride is known to exert a profound disintegrating and rearranging action on all types of hydrocarbons at relatively low temperatures. The reactions of $\mathrm{AlCl}_{3}$ with saturate hydrocarbons (normal, branched, and cyclic) can produce cyclic hydrocarbons, isomerization of cyclic hydrocarbons, lower paraffins, and olefins that, in turn, polymerize to higher paraffins. These reactions of $\mathrm{AlCl}_{3}$ on aliphatic hydrocarbons produce aluminum chloride sludges that can be used as a modified aluminum chloride catalyst for the product of aviation gasoline (Olah 1964). Little or no increase in the saturate hydrogen concentration occurred for the distillates, as measured by NMR analysis, at the temperature the $\mathrm{AlCl}_{3}$ reactions were carried out.

\section{Unsaturated Hydrocarbong}

The reaction of olefins with $\mathrm{AlCl}_{3}$ results in polymerization. This is perhaps the most important reaction, especially at low temperature. However, other reactions also can take place, such as isomerization and splitting off of lower saturate hydrocarbons. The reaction mixture consists of the polymerized oil and a halide-hydrocarbon complex. The hycirocarbon oil can be liberated from the halide-hydrocarbon complex upon addition of water. The addition of $\mathrm{AlCl}_{3}$ to the western shale oil distillates did produce a sludge or polymerized product, which was insoluble in ether and only partially soluble in $\mathrm{CHCl}_{3}$. The formation of the Alcly sludge may be the result of the reaction of heteroaromatics with AlCl 3 because no change in the olefin concentration was observed by $1_{\mathrm{H}}^{3}$ NMR. 


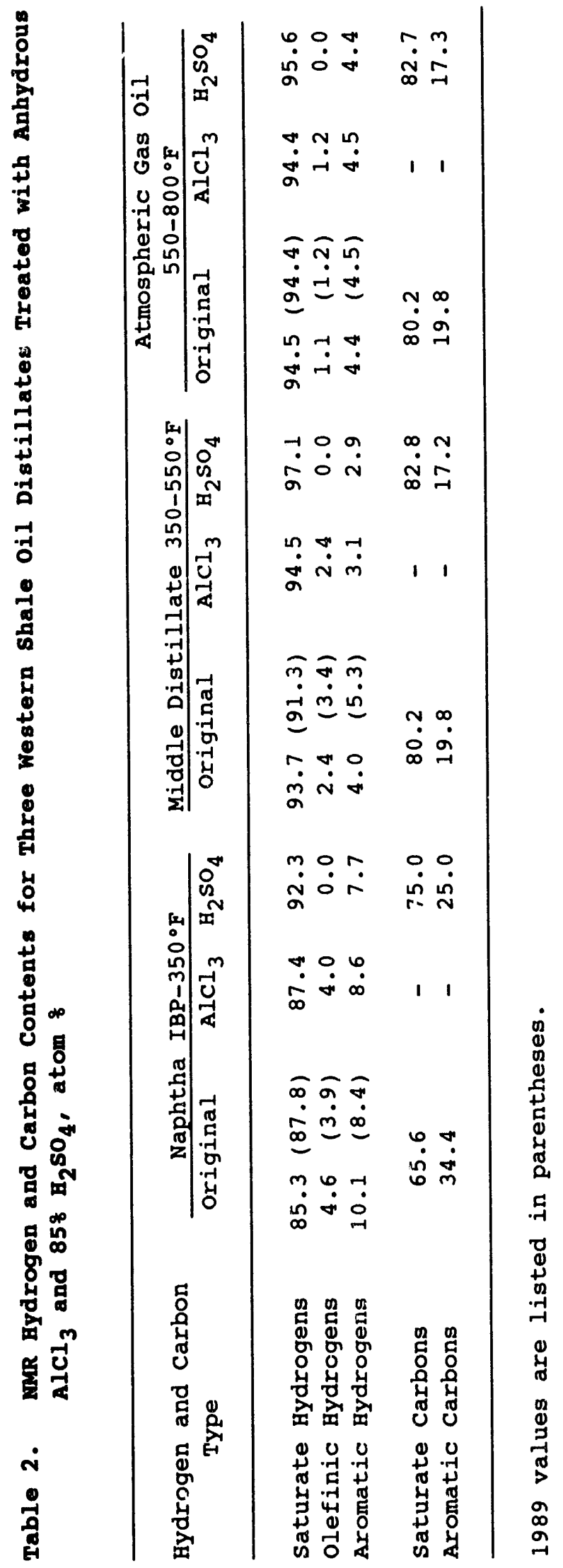




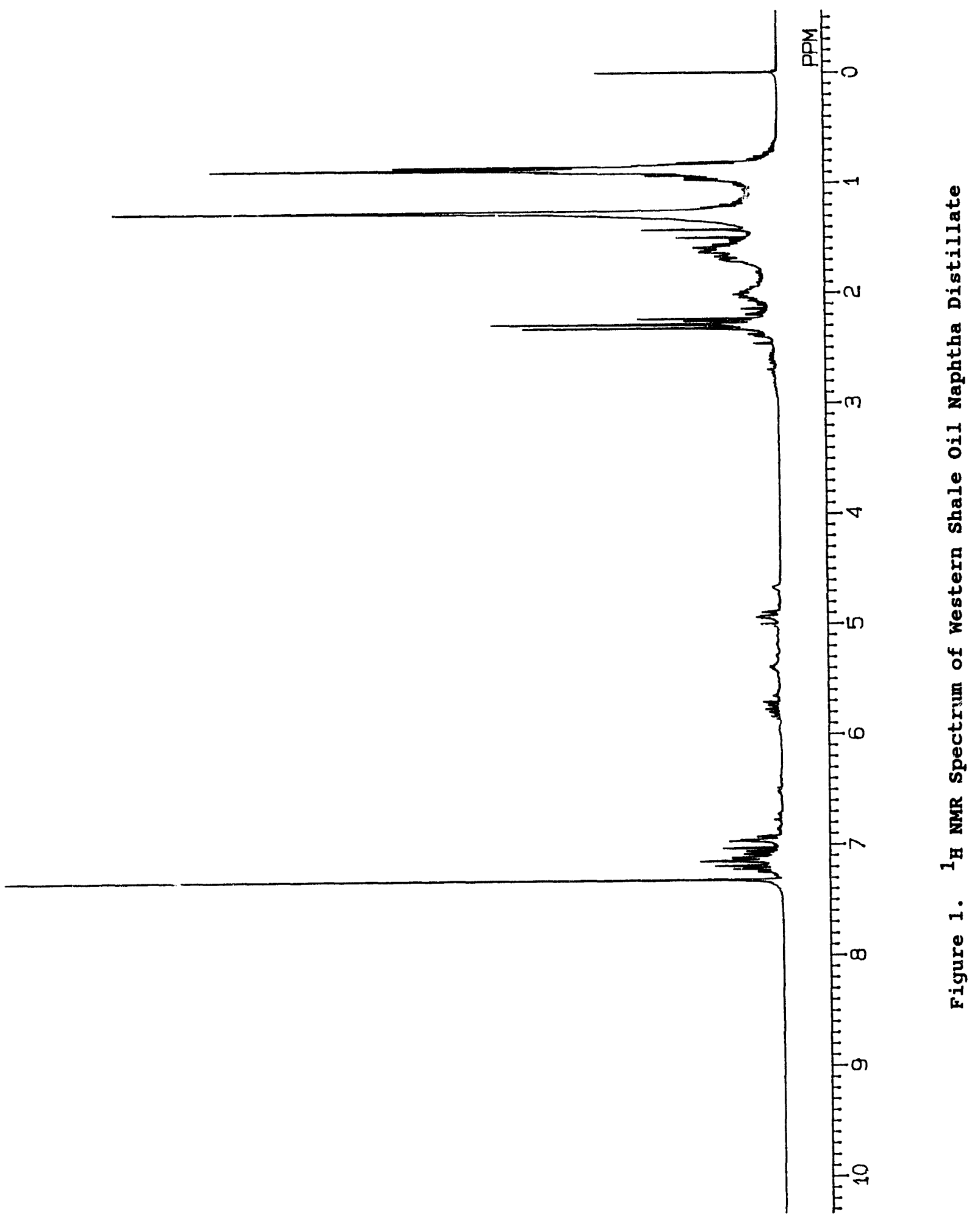




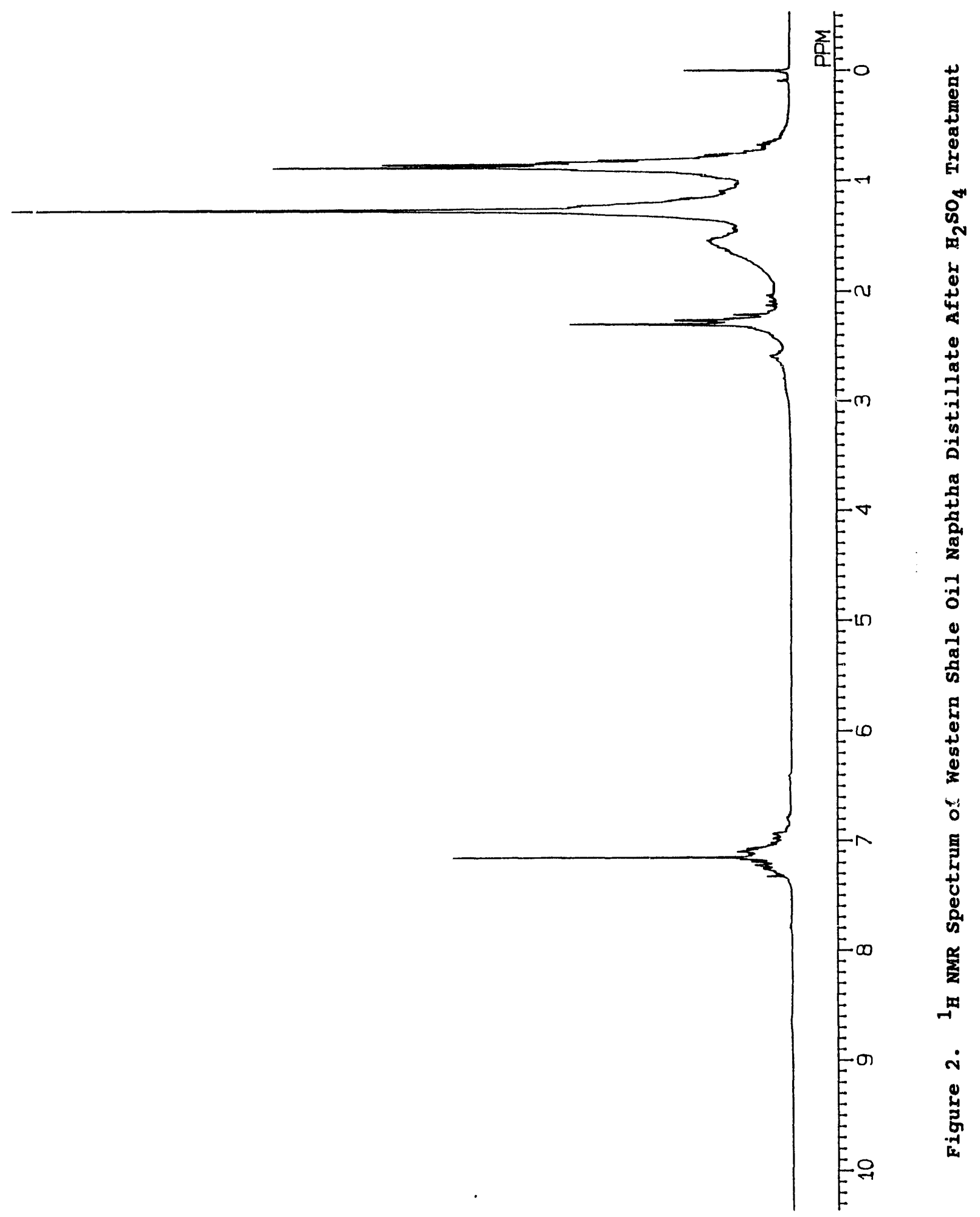




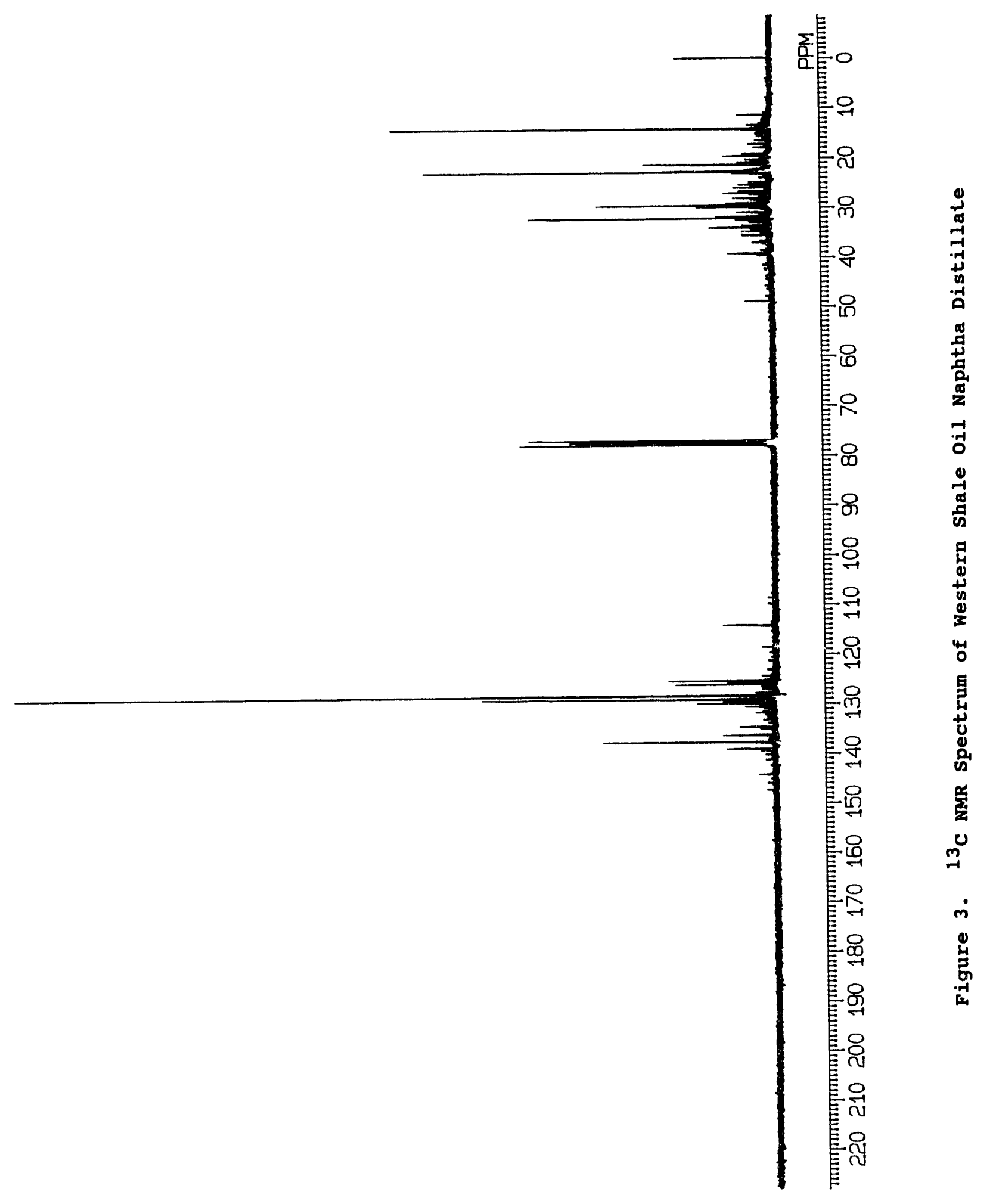




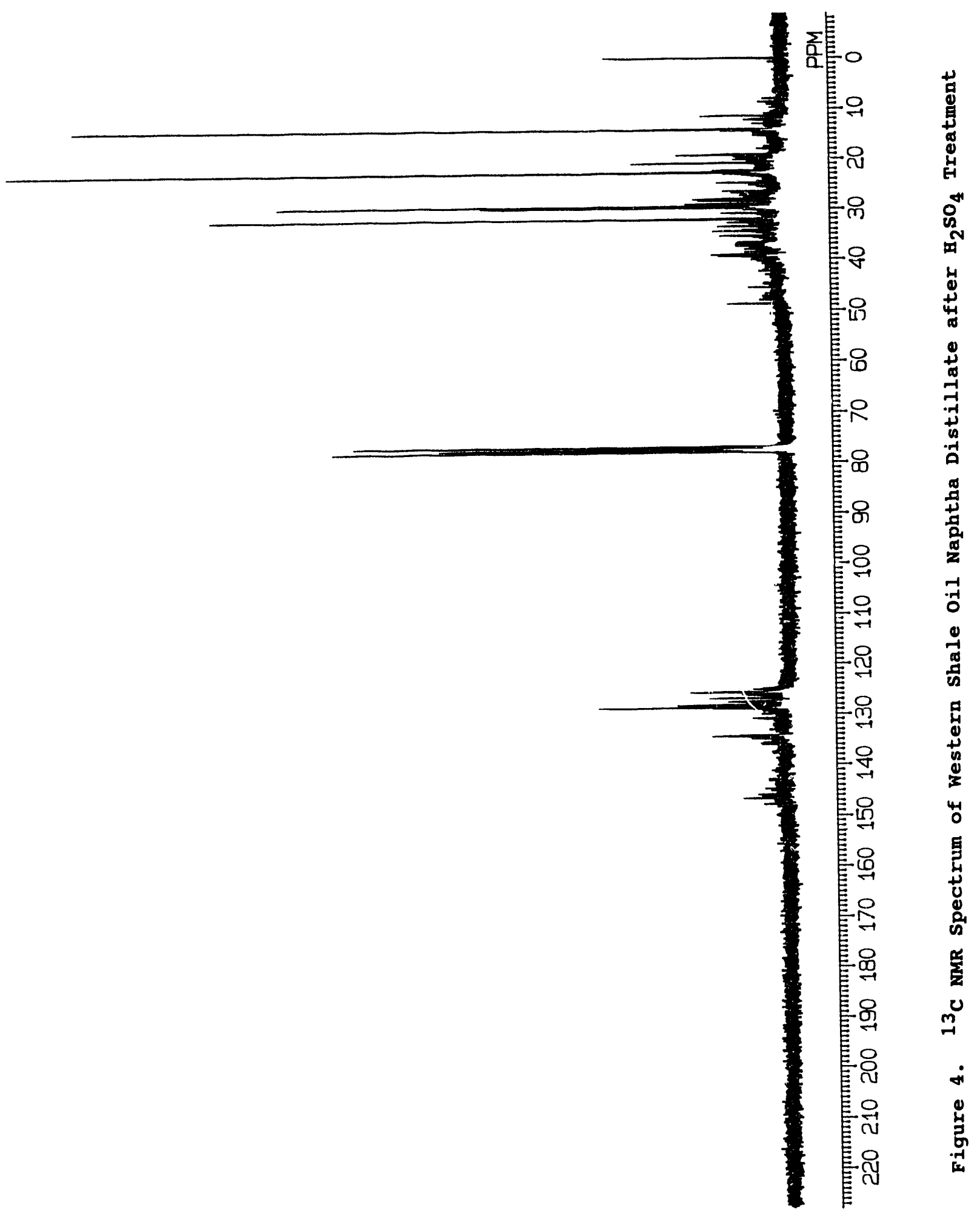


Table 3. ${ }^{1}$ H and ${ }^{13}$ C MMR Chemical shift Ranges, ppm from TMs

\section{Hydrogen Type}

Diaromatic hydrogens

$7 \cdot 2-8 \cdot 3$

Monoaromatic hydrogens

$6.6-7.2$

Alkene hydrogens

$4 \cdot 0-6 \cdot 0$

Methylene hydrogens alpha to aromatic ring

$2 \cdot 3-4 \cdot 0$

Methyl hydrogens alpha to aromatic ring

$1.9-2.3$

Naphthene hydrogens beta to aromatic ring

$1 \cdot 6-1.9$

$\beta-\mathrm{CH}_{2}-$ and $\beta-\mathrm{CH}_{3}$ to aromatic ring and normal alkane- $\mathrm{CH}_{2}-$ hydrogens

$1.0-1.6$

$\gamma-\mathrm{CH}_{3}$ to aromatic ring and normal or branch alkane- $\mathrm{CH}_{3}$ hydrogens

$0.5-1.0$

\section{Carbon Type}

Aromatic and alkene carbons

$100-150$

Aliphatic carbons

$5-50$

Methyl carbons of n-alkanes

$13 \cdot 8-14 \cdot 2$

$\mathrm{c}_{2}$-Methylene carbons of $\mathrm{n}$-alkanes

$22 \cdot 7-23.0$

$\mathrm{c}_{3}$-Methylene carbons of $\mathrm{n}$-alkanes

$31 \cdot 8-32 \cdot 0$

$C_{4,5 n}$-Methylene carbons of $n$-alkanes

$29-30$

The NMR data in Table 2 show that very little change in the olefinic hydrogen content occurred as a result of the $\mathrm{AlCl}_{3}$ reaction. In fact, the olefinic hydrogen content in the atmospheric gas oil distillate remains the same and is quite evident in the ${ }^{1_{H}}$ NMR spectrum (chemical shift range from 4-6 ppm).

\section{Aromatic Hydrocarbons}

Rearrangement and scission of side chains are the predomirating reactions of $\mathrm{AlCl}_{3}$ on alkylbenzenes, although some dehydrogenation combined with condensation also takes place. The main reaction observed in reacting polynuclear aromatic hydrocarbons with $\mathrm{AlCl}_{3}$ is one of dehydrogenation followed by condensation. 
Little or no change in the aromatic hydrogen content was observed for the three western shale oil distillates when they were reacted with $\mathrm{AlCl}_{3}$ (Table 2).

Even though some polymerization and other types of reactions occurred when the three distillates were reacted with $\mathrm{AlCl}_{3}$, significant changes in the overall composition were minimal. The lack of dramatic change in the compositions of the distillates when reavted with $\mathrm{AlCl}_{3}$ may perhaps be the result of the relatively low reaction temperature used and the inhomogeneous addition of $\mathrm{AlCl}_{3}$ to the distillates.

\section{Reactions of Shale Oil Distillates with $858 \mathrm{H}_{2} \underline{\mathrm{SO}}_{4}$}

$\mathrm{H}_{2} \mathrm{SO}_{4}$ reacts similarly to $\mathrm{AlCl}_{3}$ with organic compounds, causing isomerization, polymerization, condensation, and sulfonation. The types of reactions that occur with $\mathrm{H}_{2} \mathrm{SO}_{4}$ are strongly dependent on the concentration, amount of acid, temperature, and contact time. olefins are one of the most reactive of the organic functional groups to $\mathrm{H}_{2} \mathrm{SO}_{4}$, whereas the paraffinic or saturate hydrocarbons are the least reactive.

\section{Saturated Hydrocarbons}

Saturate hydrocarbons in the higher distillates of many oils are more reactive to $\mathrm{H}_{2} \mathrm{SO}_{4}$ than are the simpler saturated compounds (Ellis 1937). An increase in saturate hydrogen content for the three distillates is also reflected in both the ${ }^{1} \mathrm{H}$ and ${ }^{1{ }^{3} \mathrm{C}}$ NMR data (Table 2). The increase in the saturate hydrogen content is presumably the result of acid catalyzed polymerization of the olefinic molecules present in the distillates.

\section{Unsaturated Hydrocarbons}

In general, sulfuric acid reacts rapidly and completely with all types of olefins to form alcohols or polymerized saturated hydrocarbon products. ${ }^{1}$ H NMR data on the three treated distillates show complete elimination of the olefinic hydrogens.

\section{Aromatic Hydrocarbons}

The reaction of $\mathrm{H}_{2} \mathrm{SO}_{4}$ with aromatic hydrocarbons readily produces sulfonates, the main product in some types of detergents. Because these sulfonates are soluble in water, they were retained in the water phase during the oil-water separation procedure. Thus, a decrease in the aromatic carbon content should be observed. A significant decrease in the aromatic carbon content of all distillates is noted.

The extent to which alkylbenzene sulfonates were formed has not been determined. These sulfonates would be in the aqueous extraction phase, which was not analyzed. The formation of the sulfonates is confirmed by the foaming of the aqueous phase during the oil-water phase separation procedure. 
A highly viscous, tar-like material formed in the flasks ccntaining the three $\mathrm{H}_{2} \mathrm{SO}_{4}$-treated distillates after standing for one month. It is assumed that these residua are the result of delayed acid catalyzed polymerization and condensation reactions. The acid-treated naphtha distillate had the least conversion of oil to tar-like residue, and the acid-treated atmospheric gas oil distillate had the most. These tarry residua were completely soluble in $\mathrm{CHCl}_{3}$ suggesting low molecular weight polymers or associated species with moderate bonding strength.

\section{CONCLUSIONS}

The reactions of both anhydrous $\mathrm{AlCl}_{3}$ and $858 \mathrm{H}_{2} \mathrm{SO}_{4}$ on the three western shale oil distillates produced changes in the chemical composition of the distillates. Under the low-severity conditions used, $\mathrm{AlCl}_{3}$ produced few changes in the saturated and aromatic hydrocarbon composition. The $\mathrm{AlCl}_{3}-\mathrm{sludge}$ or polymerized products that formed may be the result of heteroaromatic polymerization or condensation reactions. The reactions of the distillates with 858 $\mathrm{H}_{2} \mathrm{SO}_{4}$ resulted in an increase in the saturated hydrocarbons due to polymerization of the olefins. No olefins were detected in the $\mathrm{H}_{2} \mathrm{SO}_{4}-$ treated distillates. The aromatic hydrocarbon content decreased in the treated oil. This decrease is assumed to be the result of the formation of alkylbenzene sulfonates, which were removed from the distillates by the oil-water phase separation procedure.

Even though some polymerization and condensation reactions occurred for the $\mathrm{H}_{2} \mathrm{SO}_{4}$-treated distillates during one month of storage, the use of more severe conditions during the reactions of both $\mathrm{AlCl} 3$ and $\mathrm{H}_{2} \mathrm{SO}_{4}$ with the distillates from the western shale oil should be beneficial. It should be possible to obtain more highly polymerized oil fractions that, in turn, can possibly be used as a specialty-product asphalt blending component. 


\section{ACRNOWLEDGEMENT}

We express appreciation to the U.S. Department of Energy for funding of this work under Cooperative Agreement No. DE-FC21-86MC11076.

\section{SCIAIMER}

Mention of specific brand names or models of equipment is for information only and does not imply endorsement of any particular brand. 


\section{REFERENCES}

Ellis, C., 1937, The Chemistry of Petroleum Derivatives, Volume II. Reinhold Publishing Corp., New York, NY, 1064.

Olah, G.A., 1964, Friedel-Crafts and Related Reactions, Volume II, Part 2. Interscience Publishers, New York, NY, 1093.

Sinor, J.E., 1989, Niche Market Assessment for a small-scale Western oil shale Project. Final Report. Laramie, WY, DOE Report DOE/MC/11076-2759.

Thomas, K.P., and D.E. Hunter, 1989, The Evaluation of Western Shale Oil as a Feedstock for the production of High-Density Aviation Turbine Fuel. Topical Report. Laramie, WY, DoE Report DOE/MC/11076-2888 . 
